ГАДЖИЕВ Камалудин Серажудинович, доктор исторических наук, профессор; главный научный сотрудник Национального исследовательского института мировой экономики и международных отношений им. Е.М. Примакова РАН (117997, Россия, г. Москва, Профсоюзная ул., 23; k.zuhrabvi@ gmail.com)

\title{
О БУНТЕ ПРОТИВ ИСТОРИИ В США
}

\begin{abstract}
Аннотация. В статье предпринята попытка дать анализ важнейших факторов, природы и предназначения движения «Жизнь черных имеет значение» как одного из проявлений системного кризиса, в котором США оказались в последние годы. Автор отмечает, что это движение является серьезным вызовом историческому наследию Америки - белому расизму, который имеет глубокие корни в ее общественнополитической жизни и показывает, что первоначально протесты движения проявились в разрушении и демонтаже памятников руководителям Конфедерации южных штатов во время Гражданской войны 1861-1865 гг., символов рабовладельческого Юга. Главное внимание в статье концентрируется на основных причинах и последствиях атаки участников движения на отцов-основателей, известных государственных и политических деятелей, сыгравших ключевую роль в формировании общественно-политической системы США. На этом основании автор делает вывод, что само движение и целый комплекс связанных с ним процессов и тенденций представляют собой бунт против истории США.
\end{abstract}

Ключевые слова: США, Америка, политика, расизм, “Жизнь черных имеет значение», афроамериканцы, рабство, Гражданская война, памятники, отцы-основатели, системный кризис, история, бунт

$\Pi$ о мере роста уровня цивилизации наблюдается тенденция, метафорически говоря, к девальвации, ослаблению, а то и аннигиляции веками, тысячелетиями выработанных человечеством морально-этических, мировоззренческих ценностей, норм, установок, детабуизации правил жизнеустройства и образа жизни, форм политической самоорганизации народов. Подобные явления особенно отчетливо проявляются в своеобразном бунте массы против истории, в качестве наглядного примера которого можно назвать охватившее значительную часть Запада движение за разрушение исторических памятников и символов, пересмотр, переоценку, делегитимацию и даже аннигиляцию истории и традиции.

Исторические памятники нередко способны пережить природные катаклизмы, ураганы и потопы, холод и зной, техногенные и санитарно-эпидемические катастрофы. Иногда создается впечатление, что даже время не властно над ними - тому пример египетские пирамиды, бюст божественной Нефертити, артефакты Шумера, Вавилона и т.п. Но не все памятники культуры могут пережить человеческий фактор, кровавые конфликты и войны, революции, бунты и т.д. Об обоснованности данного тезиса свидетельствует весь известный нам опыт истории человечества, в т.ч. и России. Современный мир также не свободен от подобных явлений. В качестве примера, подтверждающего данный тезис, можно привести развернувшуюся в Восточной Европе, а за ней в ряде постсоветских стран кампанию по так называемой декоммунизации и десоветизации. Так, в ходе двух майданов - 2004 и 2014 гг. - на Украине кампания отказа от российского и советского прошлого вылилась в форменное варварство и вандализм. Речь идет о публичном, всячески афишируемом разрушении памятников советского периода, в т.ч. и связанных с Отечественной войной, переименовании населенных пунктов, улиц, площадей городов.

Эта война парадоксальным образом перекинулась в США. Волна демонтажа памятников и переименования общественных мест в различных штатах и городах США достигла своего апогея в конце лета - начале осени 2017 г. Там сносили статуи героям Юга в ходе Гражданской войны в Америке 1861-1865 гг. 
- главнокомандующему армии Конфедерации генералу Р. Ли, президенту Конфедерации Д. Дэвису, генералу Пьеру Борегарду. В целом в США было зарегистрировано более ста эпизодов сноса и демонтажа памятников и памятных знаков, переименований общественных мест и других действий, преследующих цель стереть память об эпохе Конфедерации в жизни американского общества.

Эта кампания, которая, казалось, благополучно завершилась в том же 2017 г., с новой силой возобновилась после убийства полицейскими 25 мая 2020 г. афроамериканца Дж. Флойда. Начались широкомасштабные выступления, возглавляемые движением «Жизнь черных имеет значение» (Black Lives Matter). Основные эпизоды, процессы, последствия этих выступлений достаточно широко освещены в российской политической науке, публицистике и средствах массовой информации. Поэтому представляется достаточным привести лишь некоторые факты, раскрывающие природу, суть и предназначение этих выступлений.

Участники этих выступлений, направленных в начале на полицейский произвол против представителей чернокожего населения, как бы неожиданно направили свой гнев, как и в 2017 г., против памятников руководителям и военным рабовладельческого Юга в условиях Гражданской войны 1861-1865 гг.

Нельзя отрицать тот факт, что памятники служат символами исторического прошлого народа. Их свержение с пьедесталов - вопрос непростой и противоречивый, требующий весьма осторожной оценки. Особенно отчетливо такие деяния приобретают радикальный, даже разрушительный характер в периоды революционных сдвигов. Так было, например, в ходе революции 1917 г. и в послереволюционный период в России, после Второй мировой войны в Германии и т.д.

В чем-то памятники представляют не само историческое прошлое, а его версии, как его представляли их авторы. Соответственно, с пьедесталов сносятся не реальные атрибуты реального исторического прошлого, а его версии, а на их место предлагаются новые версии с точки зрения современности. Речь идет о том, чтобы избавиться от считающихся порочными событий и атрибутов истории соответствующего народа. Действительно, как выглядели бы города современной Германии, если бы там сохранились свастики, знамена, статуи Гитлера, Геринга, других руководителей, множество других символов Третьего рейха и нацизма.

В истории США было много того, чего, как говорится, можно стыдиться порядочному американцу. Речь идет, к примеру, о фактическом геноциде коренного населения, рабстве, охоте на ведьм (начавшейся еще в колониальный период с судебного процесса, проходившего в новоанглийском городе Сейлеме в 16921693 гг. против так называемых сейлемских ведьм, обвиненных в колдовстве), ку-клукс-клане, суде Линча, нейтивистском движении, маккартизме и т.д.

Памятники рассматриваются как символы и средства оправдания превосходства белой расы и угнетения афроамериканцев. В этом вопросе, возможно, прав профессор Дж. Шеферд который пишет: «В США барельеф Стоун-Маунтин продолжает играть роль святилища сторонников превосходства белой расы. Чтобы подняться на гору, афроамериканцы вынуждены, унижая собственное достоинство, проезжать мимо этих каменных идолов конфедератов, ехать по бульвару Роберта Ли, через улицу Томаса Джексона и парковаться рядом с Залом Конфедерации. Потом им надо пройти мимо четырех разных флагов конфедератов, в том числе мимо боевого знамени, в парке этого штата» 1 .

\footnotetext{
${ }^{1}$ Shepherd G. Stone Mountain and Other Monuments to the Confederacy Should Be Wiped Clean. - CNN. June 11, 2020.
} 
Этими соображениями можно объяснить тот факт, что вслед за участниками протестных выступлений снос памятников был фактически узаконен руководством Демократической партии, противостоящей администрации президента - республиканца Д. Трампа. Для обоснования данного тезиса можно привести множество примеров. Но представляется достаточным ограничиться распоряжением спикера палаты представителей конгресса США, где демократы составляют большинство, Н. Пелоси убрать из здания Капитолия 11 статуй, в т.ч. президента Конфедерации Джефферсона Дэвиса. Как утверждала Пелоси, «статуи должны воплощать наши высшие идеалы того, кем мы являемся и кем стремимся быть как страна. Статуи тех, кто защищал жестокость и варварство ради открытого расизма, являются оскорблением этих идеалов. Статуи должны быть убраны» 1 .

По-видимому, при всех возможных в этом вопросе оговорках можно понять выдвигаемые сторонниками названных акций доводы и аргументы. Но проблема состоит в том, что кампания, которая началась против символов Конфедерации, постепенно распространилась на тех исторических личностей США, которые не имели отношения к Гражданской войне, более того, решительно воевали против южных сецессионистов. Речь идет, например, о генерале У. Гранте, внесшем неоценимый вклад в победу Севера над Югом, но у которого, как оказалось, все же был один подаренный ему раб еще до начала Гражданской войны.

Казалось бы, Америку невозможно представить без ее открывателя Христофора Колумба - одного из зачинателей Великих географических открытий. Его имя носят федеральный округ, в котором находится столица страны Вашингтон, столица штата Огайо, множество менее крупных городов, несколько рек, и т.д. и т.п. В честь Колумба названа страна Колумбия, город Панамы, менее крупные города в Аргентине, Мексике, Кубе и других странах.

Тем не менее, оказывается, если принять версию нынешних революционеров, Америку можно представить без Христофора Колумба. 5 июля 2020 г., на следующий день после празднования 224-й годовщины американской Декларации независимости, небольшая перевозбужденная толпа сбросила с пьедестала памятник Христофору Колумбу в Балтиморе. Памятник ему демонтирован в Сент-Луисе (штат Миссури), а также в Сент-Поле (штат Миннесота), Ричмонде (штат Вирджиния), Бостоне (штат Массачусетс). Получается, что первооткрыватель Америки - теперь символ расизма, рабовладения и геноцида.

В Портленде снесли памятник одному из отцов-основателей США, третьему президенту США, основателю Вирджинского университета Томасу Джефферсону. Верно, что автор Декларации независимости США, в которой был провозглашен знаменитый лозунг: «Все люди созданы равными» (all men are created equal), владел рабами. Ночью группа погромщиков в том же городе сбросила на землю статую первого президента СШАДж. Вашингтона, на голове которого сожгли американский флаг. У него было около сотни рабов, которые работали в его владении Маунт-Вернон. Рабовладельцами были следовавшие за Джефферсоном президенты Дж. Мэдисон, Дж. Монро, Э. Джексон, Дж. Тайлер, Дж. Полк и др. Осквернены и снесены памятники Колумбу, президентам А. Линкольну (провозгласившему Прокламацию об освобождении рабов), Т. Рузвельту и т.д. В их число попал также автор слов гимна США («The Star-Spangled Banner») Ф.С. Ки, который, как оказалось, также владел рабами.

\footnotetext{
1 До основания: как в Европе и США разрушают историю. 14 июня 2020. Доступ: https:// www.vesti.ru/article/2421186 (проверено 30.04.2021).
} 
В Висконсине протестующие свалили и выбросили в озеро статую борца с расизмом полковника Г.К. Хэга. Кстати, от вандалов угроза исходит и упомянутому памятнику четырем выдающимся президентам США на горе Рашмор в Южной Дакоте.

Движение «Жизнь черных имеет значение» посягает даже на авторитет Иисуса Христа. Так, активист этого движения бывший пастор Ш. Кинг считает, что вслед за памятниками южанам-конфедератам должны быть снесены «статуи белого европейца, якобы Иисуса [the statues of the white European they claim is Jesus]... и заодно все фрески и витражи с изображением белого Иисуса, его матери-европейки и их белых друзей» 1 .

Школа общественных наук и международных отношений Принстонского университета, который входит в элитную «Лигу плюща», лишены имени президента США (1913-1921) В. Вильсона. Обосновывая это решение, ректор университета К. Айсгрубер заявил, что оно было принято советом попечителей, который пришел к выводу, что «расистские взгляды и политика Вильсона делают его имя неподходящим для факультета общественных и международных отношений и жилого здания колледжа, преподаватели, студенты и выпускники которых должны решительно выступать против расизма во всех его проявлениях» 2 . При этом Айсгрубер признал, что именно Вильсон «превратил Принстон из сонного колледжа в ведущий исследовательский университет», к тому же он стал президентом США и получил Нобелевскую премию мира ${ }^{3}$.

Уроженец Доминиканской Республики чернокожий Дэн эль-Падилья Перальта, известный американский историк, специалист по античному Риму, преподаватель Принстонского университета на конференции Общества античных исследований в январе 2019 г. в своем выступлении говорил о том вреде, который нанесли приверженцы классической культуры в течение двух тысячелетий оправданием рабства, науки о расах, колониализма, нацизма и т.д. По его мнению, вокруг классической традиции сформировался современный западный академический мир, который он обвинил во внедрении расизма в систему высшего образования Америки и изобретении «белизны», т.е. системы превосходства белых. Падилья поставил свою подпись под коллективным письмом, авторы которого требовали от университета «увеличить свои обязательства перед чернокожими» и превратиться в «антирасистское учебное заведение» ${ }^{4}$. Он и многие его сторонники убеждены в том, что греки и римляне не считали себя «белыми», а их бледные мраморные скульптуры в древности просто красились белой краской. По их мнению, предлагаемая ими антиклассицистская школа стала частью эшафота для уничтожения самой идеи «белого превосходства» 5 , соответственно, самой классической традиции. Как один из путей отказа от нее рассматривается роспуск соответствующих факультетов и перевод их сотрудников на кафедры истории, археологии и лингвистики. Рейчел Паузер, которая хорошо разбирается в возникших в этой сфере вопро-

\footnotetext{
1 Kristian B. The White Jesus Debate Is More Complicated than You Think. - The Week. June 24, 2020.

2 Принстонский университет за расизм исключил имя президента Вильсона из названия факультета. 27 июня 2020. Доступ: https://lenta.ru/news/2020/06/28/prinston/ (проверено $30.04 .2021)$.

3 Там же.

4 Pouser R. He Wants to Save Classics From Whiteness. Can the Field Survive? - New York Times. February 2, 2021.

5 Ibid.
} 
cax, не без оснований считает, что оценивать классическую традицию такой, какой ее видит Падилья, значит разбить зеркало, в котором она отражается ${ }^{1}$.

В этом русле обращает на себя внимание тот факт, что в США имеет место тенденция к прекращению работы разного рода лабораторий и исследовательских центров, в которых занято, как принято считать, недостаточное число сотрудников-афроамериканцев. Большую популярность получают предложения о необходимости разбавки корпуса исследователей научных учреждений представителями афроамериканцев и иных сообществ меньшинств.

В январе 2020 г., т.е. еще до убийства Флойда, Йельский университет отменил «Введение в историю искусства: от Ренессанса до настоящего времени», обосновав это решение доводами о том, что он носит евроцентристский характер и нуждается в учете опыта других регионов и народов ${ }^{2}$. Интерес представляет позиция группы американских ученых, выраженная в журнале Cell, об отношении проблем биохимии, генетики и молекулярной биологии. Сетуя на то, что среди 13 участников группы нет ни одного чернокожего, они утверждают, что такое положение, которое характерно для научного сообщества США, «эта эпидемия отрицания той важной роли, которую играют все без исключения члены общества в поддержании статус-кво, отказываясь активно бороться с таким положением, способствует процветанию открытого и системного расизма, лишая средств сушествования черных американцев, включая черных ученых» 3 . Поэтому, по мнению этой группы ученых, необходимо принять представителей афроамериканцев в редакционный совет журнала и в первоочередном порядке опубликовать их статьи.

Иногда дело доходит до абсурда. Так, власти штата Орегон усмотрели в традиционном курсе математики «идеи превосходства белой расы». Суть претензий состоит в том, что расизмом считается сосредоточенность учеников школ, например, при решении математических задач. Чтобы преодолеть этот недостаток, предлагается вести новый курс - «этноматематику». Что же такое «этноматематика»? Сам этот термин был введен еще в 70-е гг. прошлого века профессором математики университета Кампинас (Бразилия), который предлагал преподавание математики с учетом национального менталитета соответствующего народа. Как отмечают А. Рыбин и А. Приймак, «этноматематика направление в математической науке на стыке с этнологией и антропологией, которое исследует специфику математического мышления (от простого счета до сложных алгебраических и геометрических действий) у различных культур, как правило, не европейских. Особый акцент делается на “культурах без письменного выражения" ${ }^{4}$. Речь идет о методах преподавания арифметики и алгебры с учетом этнических особенностей неевропейских народов. Очевидно, что такой подход можно трактовать как признание, хотя и косвенное, превосходства белой расы перед народами других рас. Отсутствие социального и политического равенства как бы заменяется введением «пути к математическому равенству» для «ликвидации расизма в математике».

Довольно серьезные изменения происходят на «фабрике грез» - в Голливуде.

\footnotetext{
1 Ibid.

2 Hedeman M., Kristoffersen M. Art History Department to Scrap Survey Course. - Yale News, January 24, 2020. URL: https://yaledailynews.com/blog/2020/01/24/art-history-department-toscrap-survey-course/ (accessed 17.05.2021).

3 Science Has a Racism Problem. - Cell. No. 181, June 25. 2020. Р. 1443. Доступ: https://www. cell.com/cell/pdf/S0092-8674(20)30740-6.pdf (проверено 30.04.2021).

4 «Алгебра - это расизм!» - в американских школах хотят изменить преподавание математики. Доступ: https://russian.rt.com/inotv/2021-02-21/Fox-News-Algebra (проверено 17.05.2021).
} 
В исторических кинофильмах про древнюю или средневековую Европу на роли ведущих представителей ее народов назначают чернокожих. Негры играют Зевса, Ахиллеса, Энея, эльфов, рыцарей, русских князей и пр. При оценке кинофильмов художественные критерии заменяются гендерными и расовыми.

При таком положении вешей как быть с названием Колумбийского университета, портретами Б. Франклина, президентов и министра финансов при президенте Вашингтоне А. Гамильтона на долларовых купюрах и т.д., которые в той или иной форме и степени были рабовладельцами? Впрочем, и здесь решение на официальном уровне уже найдено. Интерес представляет тот факт, что предполагаемая замена портрета на двадцатидолларовом банкноте Эндрю Джексона - основателя Демократической партии в 1828 г. изображением чернокожей американской писательницы-аболиционистки Гарриет Табмен осуществляется администрацией президента от той же партии - Дж. Байдена.

Здесь парадокс состоит в том, что знаменем, символом протестного движения в США стал Дж. Флойд - наркоман, имевший семь судимостей за грабежи, кражи и наркотики, перед которым стали преклонять колени представители белого истеблишмента, сильные мира сего и похоронили в золотом гробу.

Другим парадоксом в этой сфере является тенденция к противопоставлению прав человека идее свободы. Или, иначе говоря, чтобы обеспечить права одних, оказывается допустимым нарушение свободы других. «Диссидентов, не согласных с новой идеологией, “выявляют”, заставляют раскаиваться, стоя на коленях, а непокорных ждет крах репутации и экономического положения» 1 . В подтверждение данного тезиса можно привести множество фактов, которые довольно подробно освещены в самой Америке, тем более в российской политической науке, особенно в публицистике и средствах массовой информации. Здесь представляется достаточным привести получающий некоторую популярность среди определенной части населения лозунг: «Белые жизни не имеют значения».

Еще в 60-х гг. прошлого века белая по рождению и цвету кожи известная в тот период американская писательница, кино- и театральный режиссер Сьюзен Зонтаг провозгласила: «Белая раса - это раковая опухоль на теле истории человечества». В нынешних условиях этот тезис приобрел новое звучание в новой интерпретации. Так, одна из основателей движения $B L M$ в Торонто Ю. Хогали пришла к выводу: «Белая кожа - это ненормальность, свойственная недочеловеку. Все фенотипы существуют в семье черных народов, а белые люди - генетический дефект черноты... Черные просто через свои доминирующие гены могли бы буквально смести с лица земли белую расу, будь у нас такая возможность» ${ }^{2}$. Примерно в таком же духе рассуждала в своем Twitter преподавательница Кембриджского университета П. Гопал, которая декларировала: «Сейчас у нас появилась возможность нанести решительное поражение белым, сломать их сопротивление, уничтожить их как класс и заменить их жизни жизнями цветных и ЛГБТ» 3 .

Обращает на себя внимание тот факт, что активное участие в движении, в т.ч. в рядах погромщиков, принимают участие отпрыски состоятельного белого истеблишмента, так называемая золотая молодежь. По имеющимся данным,

\footnotetext{
1 Почему Америка больше не способна навязывать другим свое цивилизационное мировоззрение. 13 июля 2020. Доступ: https://cont.ws/@galtuv/1728375 (проверено 30.04.2021).

2 Таратута М. Куда несется Америка. Доступ: https://echo.msk.ru/blog/taratuta/2671999есhо/ (проверено 30.04.2021).

3 Интеллигенция Запада разжигает ненависть против белых. 5 июля 2020. - Взгляд: деловая газета. Доступ: https://yandex.ru/turbo/vz.ru/s/world/2020/7/5/1048364.html (проверено 17.05.2021).
} 
число белых, участвовавших в протестных акциях, составляло в Нью-Йорке $61 \%$, в Вашингтоне $-65 \%$, в Лос-Анджелесе $-53 \% 1$. Или, иначе говоря, большинство участников протестных акций в этих городах составляли белые. Как справедливо отмечает ведущий «Фокс Ньюс» Т. Карлсон, идеи движения $B L M$ «десятилетиями вынашивались в университетских кампусах», причем за деньги американских налогоплательщиков ${ }^{2}$.

Утверждается новая редакция расизма, сформулированная путем перевертывания всего и вся в этой области с ног на голову. Имеет место «расизм навыворот», или «обратный расизм». Речь идет о своего рода расово-гендерном «перевороте», суть которого состоит в попытках превращения белого человека в своего рода козла отпущения. Эту метаморфозу весьма удачно описал французский писатель и философ Паскаль Брюкнер в своей книге «Почти идеальный виновный. Формирование белого козла отпущения», опубликованной в 2020 г. В ней дается анализ радикальных антирасистских и феминистских идей и теорий среди художественной интеллигенции, политической и интеллектуальной элиты, в публицистике, средствах массовой информации, которые виновником всех бед объявляют белого мужчину. Ряд ключевых положений данной книги он изложил в интервью газете Le Figaro. На вопрос: «Чем, по-вашему, объясняется идеологическая привлекательность этих теорий?» - Брюкнер ответил так: чтобы заполнить вакуум, образовавшийся после краха классических левых, возник соблазн принять гендерные, расовые теории и идеи идентичности, с помощью которых объясняют всю историю человечества. На их основе развернута широкомасштабная воспитательная кампания с требованиями «К белым отречься от себя». Этот феномен Брюкнер не без оснований называет пришедшим в Европу из Америки «под видом расистского по своей сути антирасизмом». «Единственная идентичность, которая еще допускается для белых, - утверждает Брюкнер, - это раскаяние. Неофеминисты, деколониалисты и антирасисты стыдят нас и призывают покаяться». Предупреждая об опасности следования американскому примеру, он констатирует: «Хотя Джо Байдену можно пожелать только успехов, сейчас Америка стоит перед Европой не как пример для подражания, а как провал, который нельзя повторять».

На другой вопрос: «Почему осуждение расизма и сексизма играет такую роль в современном обществе, хотя в нем еще никогда не было так мало этого самого расизма и сексизма?» - Брюкнер утверждает: «Это иллюстрация закона де Токвиля о том, что народ восстает, когда ситуация улучшается, а не ухудшается: "Жажда равенства становится сильнее по мере увеличения равенства"». Соответственно, антирасизм и антисексизм процветают по мере ослабления расизма и сексизма ${ }^{3}$. В подтверждение обоснованности данного тезиса можно привести следующий факт. Даже при множестве оговорок, положение дел в расовой сфере в США нельзя объективно оценить без учета очевидного факта довольно заметного присутствия в американском истеблишменте разных областей - бизнесе, политике, культуре, системе образования, спорте, полиции, армии, в том числе на высших должностях, и т.д. представителей различных этнических сообществ, включая афроамериканцев. Как известно, при президенте Дж. Буше-мл. пост государственного секретаря занимали афроамери-

1 Таратута М. Куда несется Америка. Доступ: https://echo.msk.ru/blog/taratuta/2671999есhо/ (проверено 30.04.2021).

2 Интеллигенция Запада разжигает ненависть против белых. 5 июля 2020. - Взгляд: деловая газета. Доступ: https://yandex.ru/turbo/vz.ru/s/world/2020/7/5/1048364.html (проверено 17.05.2021).

3 Bastié E., Bruckner P. La seule identité encore autorisée pour les blancs est l'identité de contrition. - Le Figaro. 20 janvier 2021. 
канцы Колин Пауэлл и Кондолиза Райс, два срока президентом США провел в Белом доме Барак Обама, ныне министром обороны этой страны служит Ллойд Остин и т.д. Казалось бы, этот факт говорит в пользу отсутствия в США самой проблемы расизма. Тем не менее расизм остается очевидной реальностью общественно-политической жизни США.

Полагая, что идеи, вынашиваемые активистами движения «Жизнь черных имеет значение» и теми, кто за участниками этого движения стоит, А. Лукин не без основания пишет: «По сути, на нас надвигается новая всеобъемлющая тоталитарная теория, согласно которой все общественные и исторические явления нужно будет анализировать с "расовой” точки зрения - так же, как марксисты

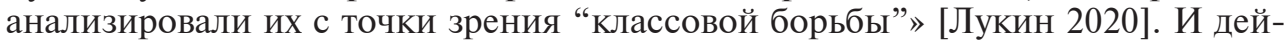
ствительно, как считают американские исследователи М. Локен и К. Звобго, «расу нельзя считать одним из подходов к международным отношениям, она центральная организующая составляющая мировой политики» 1 . И многие в научно-публицистических и медийных кругах убеждены в правоте такого рода авторов.

Создается впечатление попытки предложения всей Америке и всему миру новой версии американоцентризма в угоду идеологии политкорректности, перевернутой с ног на голову путем замены знаменитой формулы: «бремя белого человека». Разумеется, нет сомнений в том, что эти попытки, даже применительно к самим США, окажутся тщетными.

Очевидно, что эти процессы и тенденции представляют собой бунт против истории, попытка определенных сил осуществить отложенный реванш, даже акт уничтожения самой истории и исторической традиции. Поэтому для понимания их природы и значимости пример США, как представляется, дает достаточные основания для оценки банд молодчиков, которые в «цивилизованных» обществах вроде тех, кто крушил памятники советского периода, да и не только, на городских площадях и улицах Киева, Днепропетровска, Запорожья, в населенных пунктах Польши, на площадях Праги, а также памятников истории в США, странах Западной Европы, как новых варваров. Они в принципе мало чем отличаются от исламистских террористических группировок на Большом Ближнем Востоке или хунвейбинов Мао Цзэдуна.

Нередко бездумное разрушение памятников и символов нации представляет собой не что иное, как покушение на святые символы истории народа. Как справедливо констатировал Э. Канетти, «это отрицание иерархий... покушение на установленные общезначимые дистанции. Твердость изваяний свидетельствовала об их постоянстве. Они стояли издавна, считается, что они были всегда, гордые и неприступные, нельзя было даже приблизиться к ним с враждебным намерением. И вот они лежат в обломках» [Канетти 1997: 23].

Стремление начинать жить заново отнюдь не означает избавиться от зловещих фантомов прошлого. Или, иначе говоря, попытки отмены истории не означают реальную ее отмену, поскольку рабовладение навсегда останется частью истории американского народа, его национальной идентичности, национального самосознания. Можно с полным на то основанием утверждать, что расизм в самых разных проявлениях красной нитью проходит через всю историю США. Поэтому, как представляется, американцам никуда не деться, помимо всего прочего, от практически непогашенного морального долга как за рабство негров, так и за геноцид коренного индейского населения.

1 Zvobgo K., Loken M. Why Race Matters in International Relations: Western Dominance and White Privilege Permeate the Field. It's Time to Change that. - Foreign Policy. June 19, 2020. URL: https://foreignpolicy.com/2020/06/19/why-race-matters-international-relations-ir/ (accessed 17.05.2021). 
При этом осуждать всех американцев, государственных и политических деятелей США за их якобы прегрешения в этой сфере было бы не совсем корректно. Они жили и действовали в другое историческое время, с другими ценностями, правилами жизнеустройства и т.д. Слово «негр» - это не оскорбление или ругательство, а просто обозначение принадлежности конкретного человека к признанной в мировой этнологии негроидной расе. Что касается рабства, то оно существовало в течение почти всей истории человечества, в т.ч. в античной Греции даже в периоды, когда в городах-полисах власть находилась в руках тогдашних демократов. Оно в буквальном смысле процветало в самой Африке. В истории человечества, согласно марксистской классификации, существовала рабовладельческая формация. Если следовать принципам, предлагаемым участниками движения «Жизнь черных имеет значение» и его симпатантами из среды белых, то, как верно отмечает А. Финкелкраут, «мы будем вынуждены превратить историю в судебный процесс с нескончаемым списком обвиняемых» 1 .

Бунт против истории разрушает миф о США как о «сияющем граде на холме» в пример всему остальному миру, созданный усилиями многих поколений американцев. Предпринята попытка повернуть время вспять и трактовать историческое прошлое современными мерками. Прошлое Америки, судя по позициям и действиям движения «Жизнь черных имеет значение» и его сторонников, объявлено преступным. Как отмечает П.К. Робертс, «либеральная элита объявила войну фундаменту страны - отцам-основателям, конституции, математике, науке, английскому языку. Все это теперь имеет признаки “расизма". Остановить коллапс США на данном этапе уже невозможно слишком поздно» ${ }^{2}$. Косвенно признал это и экс-президент страны Д. Трамп, который заявил: «...наша нация стала свидетелем беспощадной кампании по уничтожению нашей истории, клеветы на наших героев, стирания наших ценностей» ${ }^{3}$. Удар нанесен сакральным личностям, также некоторым базовым ценностям самого народа - основателя Америки, отцам-основателям ее государственности.

Расизм меняет цвет, формируется, если уже не сформировался, «антибелый» расизм. Дело начинается с движения «Жизнь черных имеет значение», которое не допускает лозунг: «Жизнь белых имеет значение». Вполне возможно, что пока что это только на страновом уровне - в США, которые претендуют на статус «сияющего града на холме». Как-то советский/российский философ А. Зиновьев сказал про перестройку в СССР: «Целились в коммунизм, а попали в Россию». Перефразируя эти слова, можно предположить, что сейчас целятся в расистов и рабовладельцев, а попали в отцов-основателей и основополагающую ценностную систему Америки. А что если в этом вопросе остальной мир действительно станет следовать примеру гегемона? Вдруг придумают лозунги вроде: «Жизнь желтых имеет значение», а за ним лозунг: «Жизнь смуглых имеет значение» и т.д.? И где гарантия, что каждый отдельно взятый из этих лозунгов не захочет допустить подобных лозунгов других народов?

\section{Список литературы}

Канетти Э. 1997. Масса и власть (пер. с нем.). М.: Ad Marginem 527 с. Лукин А. 2020. Теория всеобщего расизма. Новая версия американского

1 Finkielkraut A. 2020. Touche pas à mon histoire! - Valeurs actuelles. 29 juillet 2020.

2 Бурханов А. Почему коллапс США остановить невозможно? Часть первая. 11 июля 2020. Доступ: https://yandex.ru/turbo/politinform.su/s/123451-pochemu-kollaps-sshaostanovit-nevozmozhno-chast-pervaja.html (проверено 17.05.2021).

3 Ibid. 
доминирования. - Россия в глобальной политике. Т. 18. № 5(105). С. 119-136. Доступ: https://globalaffairs.ru/articles/teoriya-vseobshhego-rasizma/ (проверено 20.04.2021).

GADZHIEV Kamaludin Serazhudinovich, Dr.Sci. (Hist.), Professor; Chief Researcher of Primakov Institute of World Economy and International Relations, Russian Academy of Sciences (23 Profsojuznaja St, Moscow, Russia, 117997; k.zuhrabvi@gmail.com)

\section{ON THE REVOLT AGAINST HISTORY IN THE USA}

Abstract. The article attempts to analyze the most important factors, the nature and purpose of the movement "Black Lives Matter» as one of the manifestations of the systemic crisis in which the United States found itself in recent years. The author demonstrates that this movement is a serious challenge to the historical legacy of America - white racism, which has deeply rooted in its social and political life. The article shows that initially the protests of the movement manifested themselves in the destruction and dismantling of monuments and symbols of the slave-owning South, to the leaders of the Confederation of the Southern States during the Civil War of 1861-1865. The attention is focused on the main reasons and consequences of the attack of the movement participants on the Founding Fathers, famous statesmen and political figures who played the key role in the formation of the socio-political system of the United States. On this basis, the author concludes that the movement itself and the whole complex of processes associated with it and the trend in the complex represent a rebellion against the history of the United States.

Keywords: USA, America, politics, racism, "Black Lives Matter», African Americans, slavery, Civil War, monuments, Founding Fathers, systemic crisis, history, rebellion

ЛАПШИН Аркадий Олегович - кандидат исторических наук, главный редактор журнала «Власть» (117218, Россия, г. Москва, ул. Кржижановского, 24/35, корп. 5; ark2050@yandex.ru); илен президиума Академии политической науки

\section{БЕЛОЕ ИЛИ ЧЕРНОЕ 1}

Аннотация. А. Лапшин предлагает продолжить на страницах журнала «Власть» обсуждение острейшей глобальной проблемы современности - взрыва национализма на расовой почве, поднятой в статье профессора К. Гаджиева (журнал «Власть», № 3, 2021). Автор отмечает гносеологическую ограниченность черного этноцентризма как идеологии и системы политических ориентаций. Как и в случае с классовым подходом, искажается описание исторических процессов, но, что еще важнее, при использовании этих установок в практической политике концепт черного этноцентризма приводит к драматическим результатам.

Ключевые слова: глобальные проблемы, взрыв этнизма, расизм, этноцентризм, черный этноцентризм

$\prod^{1}$ рофессор К. Гаджиев поднял острейшую проблему сегодняшней жизни, которая нуждается в глубоком научном осмыслении. В Соединенных Штатах произошел взрыв национализма на расовой основе. Черный расизм не только повлиял на повседневную жизнь американцев, но грозит стать осно-

1 Статья подготовлена при содействии к.филос.н., зам. главного редактора журнала «Власть» Т.Л. Кащенко. 